Studies in African Linguistics

Volume 32, Number 1, 2003

\title{
DYNAMICS OF INTERACTING POPULATIONS: LANGUAGE CONTACT IN THE LWOO LANGUAGES OF BAHR EL-GHAZAL ${ }^{*}$
}

\author{
Anne Storch \\ Institut für Afrikanische Sprachwissenschaften \\ Johann Wolfgang Goethe-University
}

\begin{abstract}
Number inflection systems in Western Nilotic languages appear highly complex and diverse. Comparative work on Nilotic and other Nilo-Saharan families has shown that these languages have a morphologically tripartite system with marked plurals and a bare root singular, marked singulatives constructed from unmarked collectives, and a replacement pattern with morphologically marked singulars and plurals. Historical comparison of the formatives used to construct the different number categories has proven difficult. A number of little-explored Western Nilotic languages of Bahr el-Ghazal have been in contact with Niger-Congo (predominantly Ubangi) languages and have undergone typological as well as specific grammatical changes. An investigation into the historical and present contact situations is needed in order to shed light on how the number inflection systems of these languages were created historically. Sprachbund phenomena include the diffusion of a $\mathrm{ka}$ - plural prefix into the Belanda languages, while a convergence phenomenon whose origin is probably more recent is the gradual loss of suffixing singulatives in the Lwoo languages that are in contact with Niger-Congo, which itself does not use singulatives. Retentions and innovations within the system of
\end{abstract}

\footnotetext{
* This is an expanded version of a paper presented at the Nilotic Languages Workshop at the Max Planck-Institute, Leipzig, in summer 2002. The author wishes to express her gratitude to Al-Amin Abu-Manga, Thorben Andersen, Gerritt Dimmendaal, Leoma Gilley, Clement Mur'ba Wau, Doris Payne, Mechthild Reh, Rainer Vossen, Herrmann Jungraithmayr, David Odden and an anonymous referee for their many helpful comments and their assistance in many ways. Data was collected in Khartoum with the help of Joseph Modesto, Henry Malual, Mohammed Lino Benjamin, Albert Apai Dumo, Pierina Akeelo Zubeir (Jur-Luwo), Philip Dominic Kyawa and Peter Philip Tuyugi (Belanda Bor) to all of whom I am deeply grateful. The author wishes to thank the Deutsche Forschungsgemeinschaft for generously supporting the research project "Systems of Nominal Classification in Western Nilotic".
} 
number inflection of certain Lwoo languages of Bahr el-Ghazal are discussed and analysed in terms of the history of these languages. This paper argues that crucial changes and differences within Western Nilotic noun morphology cannot be understood without taking into account the long and complicated contact history of these languages.

\section{Introduction}

In the nominal system of a language which is in close contact with a typologically different language, number marking is a feature which easily changes. Singular and plural categories such as singulatives, collectives, mass items, plurals of countable objects etc. do not necessarily appear in every language. As marked structures, they are often eliminated by language contact. Besides simplifying a formerly rich system, language contact may also result in the transfer of grammatical elements: number-marking techniques and patterns may be borrowed, so that the system of one language converges with that of another instead of simply being reduced.

Contact-induced changes of nominal systems have been described for a number of African linguistic areas. In the contact zone of Benue-Congo and Chadic in north-eastern Nigeria, both Bole-Tangale (Chadic) and Jukun (BenueCongo) lost their grammatical gender and noun-class systems and significantly lack nominal plural formation (cf. Jungraithmayr \& Leger 1993; Storch forthcoming). Some Semitic languages of Ethiopia almost totally lack the dual-number category due to language contact with Cushitic (Thomason 2001: 65; Leslau 1945). Other examples include the Nilotic-Bantu contact area, where Luo incipiently acquired a noun-class system typologically related to Bantu (Dimmendaal 2001 b: $97 \mathrm{ff}$.). In all three cases, language contact has led to radical typological restructuring. For example, in Jukun (which is in contact with Chadic), the semantically and morphologically complex number marking system deriving from Proto-Niger-Congo noun classes is reduced to a distinction between singulars and plurals of humans. Most non-human and all inanimate objects are not numbermarked, as they do not distinguish the plural anymore. The prefixed noun class markers of Proto-Jukunoid have been lost or are lexicalized, and the concord markers largely went the same way. The result is a typological pattern very much resembling the Kwa characteristics classically outlined in Westermann (1927). Williamson (1985) presents a case study of the typological changes observed in the Ogoni languages spoken in the Niger delta in eastern Nigeria which (unlike in 
Jukun) may not be due to language contact, and which led to a similar "Kwatype" isolating structure of a formerly rich morphological nominal system. This example, too, illustrates a case of extreme reduction of number marking.

Being a region with much language contact, Bahr el-Ghazal in SouthWestern Sudan provides an example of related phenomena of linguistic interference which include significant morphological convergence in the nominal system. Typologically, however, the languages of Bahr el-Ghazal that are involved in these contact phenomena remain conservative in retaining tripartite number marking and the use of suffixes. This distinguishes the language contact situation described here from the cases mentioned above. The contact situation dealt with in this paper involves primarily Belanda Bor, a Northern Lwoo language of the Western Nilotic sub-family (Nilo-Saharan), and Bviri, which belongs to the Banda-Gbandi-Sere group of the Ubangi family (Niger-Congo). Contact between Nilo-Saharan and Niger-Congo is certainly not the only example of linguistic interference observed in our research area. Contact between members of the same phylum and family also occurs, so that various convergence phenomena of different origins can be identified.

MAP 1: Northern Lwoo and Sere Languages of Bahr el-Ghazal

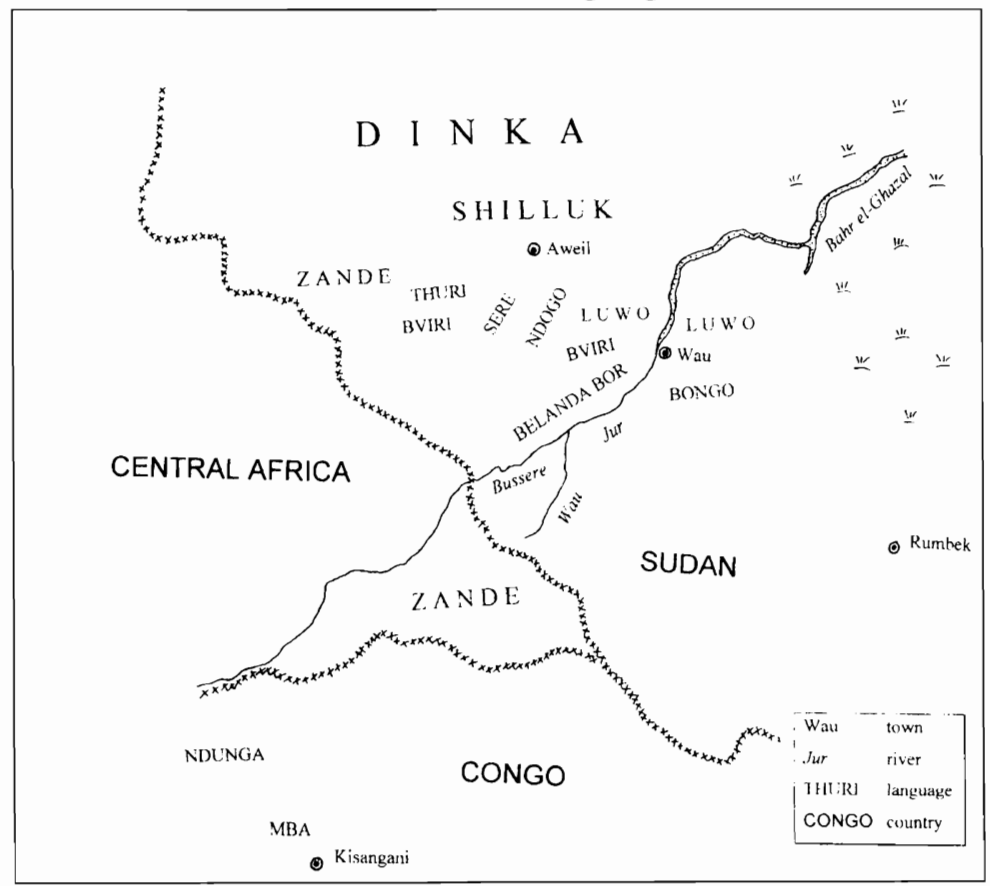


The approximate geographic location of Northern Lwoo and the Sere languages is shown on the map (modified from Santandrea 1946). A more current statement of the distribution of the languages cannot be given at present, as fieldwork in the area is not possible.

Data focussing on noun morphology and on the structures of noun phrases in Western Nilotic were collected by the author in Khartoum in 2000 and 2002. Research was conducted on Burun (Mayak), Mabaan, Jumjum, Dinka-Padan and Dinka-Rek, Nuer, Shilluk, Luwo ("Jur"), Päri, Thuri, Bor (Belanda) and Acoli. For the following languages, published sources have been used as well: Burun languages (Andersen 1992, 1998, 1999a-c, 2001), Anywa (Reh 1996, 1999), Shilluk (Gilley 1991, 1992, 2000a-b; Kohnen 1933; Westermann n.d.), Päri (Andersen 1988a-c, 1989; Simeoni 1979), Agar Dinka (Andersen 1987, 1995), Luo (Tucker 1994), Alur (Knappert \& Ukoko 1964) and Lango (Noonan 1992). For Luwo (Jur) on which this paper partly focuses, Santandrea (1946) and Buth (1981a-b) provide noteworthy sources.

On the Niger-Congo side, we find that Banda-Ngbandi-Sere languages of Sudan are poorly documented. Santandrea (1961) and Behagel (1988) using data collected by Boyd are the only published sources on Bviri available to the author. A thesis on the noun phrase in Bviri is in progress at the University of Khartoum (L. Gilley \& Clement Mur'ba Wau, pers. comm.).

The classification models for the Lwoo group (Reh 1996: 4 following Rottland 1981: 269) and Bviri (Boyd 1989: 194) are as follows:

\section{Table 1: Classification models.}

Nilo-Saharan
Eastern Sudanic
Nilotic
Eastern Nilotic
Southern Nilotic
Western Nilotic
I. Burun
II. Dinka-Nuer
III. Lwoo

a. Northern (Shilluk, Anywa, Päri, Luwo, Thuri, Belanda Bor)

b. Southern (Acoli, Luo, Alur, Labwor, Kumam, Lango) 


\section{Niger-Congo \\ Ubangi
a) Gbaya
b) Banda-Ngbandi-Sere
c) Zande

Ngbaka Mba Sere/Bviri

Of the three sub-families of Nilotic, Western Nilotic is probably the least studied. The lack of adequate data and analyses of many Western Nilotic languages and lects partly results from the long-lasting political, religious and ethnic tensions in southern Sudan and northern Uganda, which make field research in much of the Western Nilotic area almost impossible. Another reason for the lack of comparative and reconstructive work may be the highly complex phonology obscuring the diversified noun morphology: Oswin Köhler who can be regarded as the founder of comparative Nilotic studies, is said to have once remarked that adequately describing Western Nilotic or reconstructing its Proto-language would be a hopeless undertaking, as this language group could be best termed a Steinbruch - a quarry with some eroded remains of a once complex system (F. Rottland, pers. comm.). This paper attempts to explain part of the sub-family's structural diversity as a result of different strata of intergenetic and intragenetic convergence. As a contribution to the group's linguistic history, it is hoped that this will lead to further investigations into the development of Western Nilotic systems of noun morphology.

A look at a rather uncomplicated sample of Western Nilotic noun forms illustrates the intragenetic diversity:

\section{Table 2: Western Nilotic noun forms for 'intestines liver'.}

\begin{tabular}{|c|c|c|c|}
\hline Language & Collective & Singulative/Plural & Group \\
\hline Mayak & 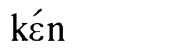 & k'́nàt & Burun \\
\hline Mabaan & kyénnù & kyétgò & \\
\hline Jumjum & kénnù & $k^{\prime} \varepsilon_{-}^{t}$ & \\
\hline Dinka Padan & cùćn & cụ̣ç̣n & Dinka-Nuer \\
\hline Dinka Rek & cùćn & cựạn & \\
\hline Nuer & cùćn & cùân & \\
\hline Luwo & cwín & cwine & Lwoo \\
\hline Anywa & cwin & cwinní & \\
\hline
\end{tabular}




$\begin{array}{lll}\text { Päri } & \text { cwin } & \text { cwinji } \\ \text { Shilluk } & \text { Ú-cwín } & \text { Ú-cwin } \\ \text { Belanda Bor } & \text { sún } & \text { kásún } \\ \text { Thuri } & \text { ć́n } & \text { ć́nè } \\ \text { Acoli } & \text { cwín } & \text { cwíngé } \\ \text { Lango } & \text { cún } & \\ \text { Dholuo } & \text { cún } & \text { cụnje }\end{array}$

The root reconstructed for 'intestines, bowels' in Proto-Nilotic is *cin (Dimmendaal 1988: 33), and has been retained in all branches of Western Nilotic. The Burun group clearly differs from the two other sub-groups of Western Nilotic. These languages exhibit an unvoiced palatal plosive $/ \mathrm{k} /$ or palatalized $/ \mathrm{ky} /$ instead of initial / $/$. Mabaan and Jumjum employ a suffix $-u$ or $-N u$ to construct the collective form, and suffix the morpheme complexes $-\grave{a}-\underline{t}$ and $-\underline{t}-g \grave{\partial}$ to construct singulatives or plurals. A detailed analysis of Mabaan number inflection is presented in Andersen (1998).

In Dinka-Nuer, number marking is indicated by tone and vowel changes. Observe the change from creaky voice vowels $[\grave{u} \bar{\varepsilon}]^{1}$ to breathy voice vowels [üç in Dinka, and the change to a voiceless breathy vowel [áa] in Nuer. In the Lwoo languages, number is marked by affixes rather than apophony. We observe the suffixes -e, -ní, -ji, -je and -ge as well as a prefix ká-which occurs exclusively in Belanda Bor. The $U$ prefix of Shilluk does not mark number, but is a derivational morpheme. All Dinka-Nuer and Lwoo forms in the "collective" column exhibit morphologically simple structures in Lwoo and [-breathy] vowels in Dinka-Nuer. In the "singulative/plural" column we find morphologically more complex forms.

The examples in table 2 also help to illustrate - besides comparability of morphological structures - that Western Nilotic nouns do not necessarily occur in a singular and plural form. The liver, like meat, for example, is perceived as a collective or mass and not a single item. The morphologically less salient form is grammatically collective. In some cases, e.g. in Belanda Bor, the morphologically unmarked form — sún — means '(a) liver' and the salient form — kásún — means 'livers' (the same holds true for most Southern Lwoo languages). But Luwo for instance uses the unmarked form in the first column for something like 'liver as a mass', while the suffix-marked form in the second column has the meaning of 'quantities pieces of liver'. Here, the singulative / plural derives from

\footnotetext{
${ }^{1}$ Creaky voice will not be marked; all Dinka/Nuer vowels that are not breathy are necessarily creaky.
} 
the collective. Collective here labels items that cannot be counted, for example liquids, dust, sand, meat, gruel etc. Things that naturally occur in masses or larger numbers, such as birds, locusts, hair, ribs, fingers etc. are also treated as collectives in Western Nilotic.

A singulative form in the sense of 'piece of liver' can be derived for example with the help of a particular suffix in many Lwoo languages. In some cases, however, such a form has the connotation of a plural, as in Mayak or Acoli, where it means 'pieces of liver' (but never 'livers'). The liver is regarded as the seat of the soul by many Nilotic peoples, and with this meaning, the word may also have a true plural that is not referring to a large number of singled-out items.

A singulative noun is typically a word that denotes an item that is singled out from a mass or group of similar items. Items that normally occur in pairs or larger numbers are semantically and grammatically plural or collective and morphologically not overtly marked. Verb concord, however, often is in the $3^{\text {rd }} \mathrm{sg}$. when the subject noun is collective (as it is the case e.g. in Luwo). A modifying adjective or any other modifier is plural. Compare the following example from Anywa (Reh 1996: 133):

$$
\begin{aligned}
& \text { wàr }+* / g \bar{V} / \quad * / \text { wàrg } \bar{V} / \quad * / \text { wàJJVIV } / \text { wànn } . / \\
& \text { 'shoes' + plural } \rightarrow \quad \text { reconstruction } \rightarrow \text { reconstruction } \rightarrow \text { 'shocs of' }
\end{aligned}
$$

To single out one object (e.g. 'one shoe, one ear, one piece of meat, a drop of liquid'), a singulative suffix is added. Singulatives and singulars differ in so far as the first is underlying plural. Singulatives are a rare phenomenon world-wide, but are characteristic of Nilotic as well as other Nilo-Saharan language families. Besides Nilo-Saharan, Arabic exhibits singulatives. Examples are:

$\begin{array}{llllll}\text { šağar } & \text { 'wood, forest' } & \text { šăgara } & \text { 'tree' } & \text { aš̆ar } & \text { 'trees' } \\ \text { fikr } & \text { 'thought' } & \text { fikra } & \text { 'idea' } & \text { fikrayāt } & \text { 'thoughts' } \\ \text { kalim } & \text { 'speech' } & \text { kalima } & \text { 'word' } & \text { kalimāt } & \text { 'words' }\end{array}$

The basic form consists of the three radicals (root consonants) plus a particular vocalisation pattern and denotes uncountable objects. The collective noun šăar morphosyntactically behaves as singular, i.e. verb agreement is in the $3^{\text {rd }}$ sg. This parallels the behaviour of collectives in Western Nilotic. In Arabic, the noun cannot be modified by numerals, which differs from the Western Nilotic example (1). 
The Arabic singulative is constructed with the feminine suffix $-a$. As in Nilotic, this form is grammatically and semantically singular. In Western Nilotic, a 'piece of liver or meat, bird, tooth' etc. behave morphosyntactically as singulars and take singular modifiers (c.f. Reh 1996: 132). The Arabic singulative form then can be transformed into a plural, e.g. with the feminine plural ending -att.

On the Niger-Congo side of the contact area, in turn, singulatives do not occur. The Ubangian Banda-Ngbandi-Sere group exhibits remnants of noun classes, where the Mba languages are the only languages which still possess a fully functioning noun class system, and only use noun class suffixes (Boyd \& Pasch 1988: 53). The Sere languages have not retained this system. Number is marked in the plural only, where a prefix appears. This prefix is not class- or gender-sensitive. Compare the following example:

(3) 'stone' (Behagel 1988: 129)
diŕl
pl. ka-dırı́
(Bviri)
Sere group
t'́mé-le
pl. t'́m'́s-se
(Ndunga-le)
Mba group

\section{Patterns of Northern Lwoo noun morphology}

The Lwoo languages form one of three coordinate branches of Western Nilotic according to the above classification model. Lwoo then divides into Northern and Southern Lwoo, where Southern Lwoo languages apparently are much more closely related to each other than Northern Lwoo. As shown by Dimmendaal (200lb: 97 ff.), certain morphological features of Southern Lwoo can be attributed to convergence with neighbouring Bantu languages. For Northern Lwoo, morphological convergence with various non-Lwoo languages is only briefly discussed in Ehret (2001) and Dimmendaal (2001b) as a possible explanation for the group's internal diversity.

Reh (1996) presents a detailed analysis of the nominal system of Anywa and systematizes the morphological elements involved in number marking. The grammatical number marking system of Anywa is bipartite, whereby nouns can either be singular or plural. Nouns ending in $-5,-a$, or $-U$ are always singular, while nouns ending in $-\varepsilon$ are always plural. Nouns ending in $-I$ or $-i$ are either singular or plural. Prefixes never indicate number, but have derivative functions. The morphological number marking system in Anywa is tripartite. Anywa has singularized, pluralized and "opaque" nouns that are characterized by the absence of any number-marking morpheme; they consist of the nominal stem only. Reh (p. 96) distinguishes the following types of number-marking in Anywa: 


\section{Table 3: Anywa number marking.}

\begin{tabular}{|c|c|c|c|c|c|}
\hline & $\begin{array}{l}\text { matical: } \\
\text { hological: } \\
\text { example }\end{array}$ & $\begin{array}{l}\text { singular } \\
\text { singularized }\end{array}$ & $\begin{array}{l}\text { plural } \\
\text { opaque }\end{array}$ & pluralized & pattern \\
\hline $\mathrm{A}$ & 'body' & & dèel & " dèedd́ & plural suffix \\
\hline B & 'eggs' & tòn̄̄ & tòy & & $\begin{array}{l}\text { singulative } \\
\text { suffix } 1\end{array}$ \\
\hline $\mathrm{C}$ & 'lover' & lùobò & lùob & & $\begin{array}{l}\text { singulative } \\
\text { suffix } 2\end{array}$ \\
\hline$D$ & ‘paper’ & wèelō & & wéclí & $\begin{array}{l}\text { replacement } \\
\text { pattern } 1\end{array}$ \\
\hline$E$ & 'fieldguard' & kùrì & & kùyyè & $\begin{array}{l}\text { replacement } \\
\text { pattern } 2\end{array}$ \\
\hline
\end{tabular}

The singular suffixes in Anywa are $-\bar{j},-\bar{i}, \bar{j},-\bar{a},-\bar{U}$. Non-segmental singular morphemes also occur, as example (D) in table 3 suggests. The vowel change from [-breathy] to [+breathy] observed in $(D)^{2}$ as well as in a large number of examples in Reh (p. 99 f.) are not necessarily due to regressive vowel assimilation (p. 100) and cannot be reconstructed as a result of suffix assimilation. Reh assumes that the observed vowel changes are the reflex of a third morpheme which, besides being a stem-forming and number suffix, has or had a yet unknown function. Another non-segmental morpheme appears e.g. in rénnh', pl. rìdh 'fin', where the singularized form exhibits nasalization plus reduplication of the stemfinal consonant. The vowel shortening apparently goes together with this morphophonological process. Reh suggests a morpheme $-V N$ - as a possible cause for the observed changes.

The plural suffixes in Anywa are $-Y \bar{\varepsilon},-\grave{\varepsilon},-C \bar{l}$, and $-\grave{l}$. Non-segmental formatives such as internal changes of the vowel (voice changing, shortening) or the consonant (deletion, reduplication, plosivization) are observed as well. Number marking in Anywa involves various strategies and techniques, whereby the different morphemes can be combined.

\footnotetext{
${ }^{2}$ Anywa vowels combine the phonological features [breathy voice] and [expanded pharynx], so that it is not necessary to mark both of these properties. The vowel qualities are therefore represented by the symbols for [+/- ATR].
} 
The large variety of number marking devices of Anywa (and - according to Gilley 2000 - of Shilluk) is not found in the Southern Lwoo languages where plural marking is highly reduced and there are no productive patterns. While Gilley suggests a semantically based principle as a possible source of the manifold patterns of number marking, Reh (1996; Anywa) and Dimmendaal (2000; Surmic) assume that phonological features of the stem are in many cases, though not all, responsible for the evolution of the complex system such as found in Anywa. The basic principles of this system have not yet been fully worked out, but as the thorough analysis of other Western Nilotic languages advances, the regularities and common patterns of the languages will probably be better understood. One aim of this paper is to consider whether contact-induced reductions of the morphologically and morphophonologically rich system of many sub-branches of East Sudanic affect certain devices more than others, and to consider whether a general system or typological pattern is still mantained.

\section{Modifications of the tripartite system}

Before we take a look at the contact situation of the Belanda languages, it is necessary to understand the historical modifications to the number marking system which occur in Northern Lwoo of Bahr el-Ghazal. It will be shown in this section that a number of Lwoo languages are influenced by Western Nilotic Dinka (Luwo), Central Sudanic and Ubangi languages (Thuri), but there isn't any clear evidence that this has caused any change in the number marking systems of these languages.

Luwo ("Jur") is spoken west of Anywa in Bahr el-Ghazal. Speakers of Luwo claim to have always been bilingual in Dinka, a Western Nilotic language spoken to the north and east of Luwo. Other languages in contact with Luwo are Ndogo (Ubangi), Bongo (Central Sudanic) and Thuri (Western Nilotic).

Luwo has fewer number marking suffixes, when compared to Anywa.

(4) Number marking in Luwo (Santandrea 1946)

$\begin{array}{llll} & & \text { sg. } & \text { pl. } \\ \text { A 'chief' } & \text { ruoth } & \text { ruodhen } \\ & \text { 'tongue' } & \text { lep } & \text { leben } \\ & \text { 'head', } & \text { wic } & \text { wudhen } \\ \text { 'street' } & \text { yo } & \text { yedhen } \\ & \text { 'leopard' } & \text { kwac } & \text { kwanyen }\end{array}$




$\begin{array}{llll}\text { B } & \text { 'fish' } & \text { reyo } & \text { rec } \\ & \text { 'bone' } & \text { coo } & \text { cuu } \\ \text { C } & \text { 'spear' } & \text { ton } & \text { tón }\end{array}$

Santandrea (1946) does not give any rules for plural formation in Luwo, but remarks that most of the recorded plurals are irregular (p. 7). Example (4) presents these forms in an order which makes it apparent that the morphological number marking system of Luwo is basically as in Anywa, but it seems to lack the large variety of morphemes. Plurals of group (A) are formed with a suffix -en that causes various changes of the final stem consonant. Group (B) singulatives are formed with a singulative suffix $-o$; the plural forms are morphologically unmarked. Group (C) simply employs tonal alternation to mark number.

According to recent research conducted by the author, the Luwo number marking system is tripartite. The recorded nouns are either marked as singulatives and have a bare root for collectives, or they are morphologically marked as plurals with a bare root for singulars; a third category marks both, singulars and plurals. When number is morphologically marked, this is always done with suffixes (plus vowel and/or tone alternations): prefixes never indicate number in Luwo.

Singulatives are constructed with a tone-copying suffix -o, plurals are marked with a suffix $-e$ (which copies the stem tone as well) or $-C e$ plus a possible morpheme $-V-.^{3}$ The two possible singular forms for 'hippopotamus' suggest that the system has begun to disintegrate, as affixes lose their semantic and functional load.

(5) Tripartite number marking system

\begin{tabular}{|c|c|c|c|}
\hline 'meat' & rìj & rin & singulative \\
\hline 'cheek' & pínó & pin & \\
\hline 'tooth' & l'́ęyó & làk & \\
\hline 'body' & kwom & kòme & plural \\
\hline hippopotamus' & páar & párré & \\
\hline 'giraffe' & wìr & wúrè & \\
\hline
\end{tabular}

\footnotetext{
${ }^{3}$ The suffix - en recorded by Santandrea is missing and could have been shortened to - e. As dialectal differences have not been explored. however, the possibility that two different dialects have been recorded cannot be excluded.
} 


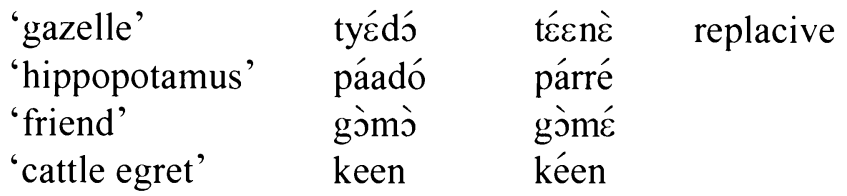

The inflectional affixes which are present in Northern Lwoo are not used at all in one of the languages in contact with Luwo, namely Dinka (Jieen), and are used to a much lesser extent in adjacent Nuer (Naath). In Dinka, the basic devices of plural formation are, according to Nebel (1948):
a) vowel lengthening
b) vowel shortening
c) vowel alternation and vowel changes
d) mutation of the stem-final consonant
e) suppletion

Data collected by the author largely support these observations. Luwo is characterized by convergence with Dinka in numerous ways. The many lexical loans from Dinka which were identified in the Luwo vocabulary, as well as similarities in the vowel systems of both languages, support our assumption that the gradual loss of number-marking suffixes in Luwo also results from intensive contact with Dinka, which itself exhibits a number marking system that does not use affixes.

But how else can the tripartite system of Lwoo be modified, and which other contact languages are involved? The Luwo system of number inflection strongly resembles that of Anywa, Shilluk and Päri, but the variety of suffixes is reduced due to convergence with Dinka. Further west and south of Luwo, intensive contact with Niger-Congo plays a significant part in the development of further modified number inflection systems of certain Lwoo languages.

The Northern Lwoo language Thuri and the Southern Lwoo language Acoli are examples of reduction of tripartite number marking patterns. Thuri is spoken by some 6000 individuals in small pockets in western Bahr el-Ghazal, around the towns of Deim Zubeir and Bora. The Thuri are surrounded by Ubangi-speaking groups - Zande, Bviri, Sere - and claim to be multilingual speakers of their own and the neighbouring languages. Convergence with Niger-Congo languages led to a gradual loss of the singulative noun forms, which are one category in Western Nilotic of the tripartite number marking system. Singulatives, however, do not exist in Niger-Congo. Thus, Thuri has lost its "classic" singulatives. It has a very few innovative singulatives which are constructed with a grammaticalized 
prefix ji- 'child; daughter' instead of the old suffix - $O$ (see example (6c)), and it employs a wide range of singular and plural suffixes in the two remaining grammatical patterns. Because singulatives have been defined as morphologically salient forms that are derived from morphologically unmarked collective forms (cf. section 1), the non-plural suffixes in the replacement-pattern forms have to be interpreted as singular markers and not as an additional category of singulatives.

The vowel changes observed in (6a) and (6b) are due to vowel harmony. Thuri has two sets of [ $+/$-advanced tongue root] vowels that are mutually exclusive within words.

(6) Simplification in Thuri

a. Plural suffixes $-\varepsilon n /-e n,-\varepsilon /-e,-1 /-$ i:

$\begin{array}{lll}\text { 'male' } & \text { cuów } & \text { cwòwen } \\ \text { 'name' nín } & \text { nínén } \\ \text { 'throat' } & \text { lúor } & \text { lúorì }\end{array}$

b. Singular suffix -a, -o (replacement pattern):

$\begin{array}{lll}\text { 'heart', àdúulá } & \text { àdúulén } \\ \text { 'thing' gùbó } & \text { gùbén }\end{array}$

c. Singulatives (rare; 11 out of 230 lexical entries):

'birds' wên jìwenó

Even though singulatives in Thuri are not constructed with the Western Nilotic suffix but instead use a new prefix, they are still a valid category within the number inflection system. This is not necessarily the case in southern Lwoo.

Acoli is spoken in Equatoria Province of Southern Sudan and the adjacent parts of Uganda. Neighbouring groups with whom Acoli speakers seem to have been in close contact for a long time are speakers of Eastern Nilotic, Surmic, and Bantu, as well as others. Acoli - as well as most other Southern Lwoo languages - has almost entirely lost the morphologically rich and grammatically complex number marking system; most nouns have a morphologically unmarked singular and a periphrastic plural form with lwàk 'crowd; many items of'. Morphological plural formation has been given up to a large extent. A few morphologically number-marked forms have been recorded, and it seems that all of them fit into the replacement pattern. Singulars are mostly marked with an $-O$ suffix as e.g. in Luwo and Thuri. 
(7) Simplification in Acoli

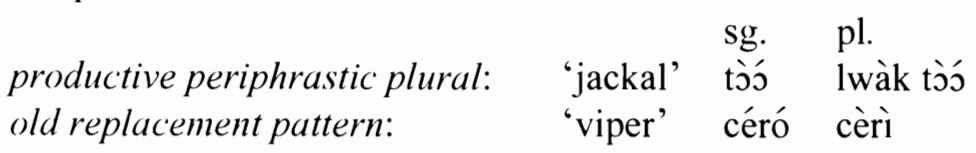

From this brief comparison we may conclude that besides morphological changes, the tripartite pattern of number marking was gradually simplified in Lwoo. Anywa with its complex structures of singular-, singulative- and pluralmarking may be taken as a typical system, as it corresponds to tripartite systems in numerous groups of Eastern Sudanic or even Nilo-Saharan. Dimmendaal (2000) suggests that tripartite number-marking systems of considerable morphological and morphophonological complexity are a charactistic feature of the whole phylum and should be reconstructable for Nilotic as well as for many other sub-branches within Nilo-Saharan. Examples from the Surmic language Baale are taken from Dimmendaal (p. 220 ff.):

(8) Tripartite number marking in Baale

$\begin{array}{lllll} & \text { sg. } & \text { pl. } & & \\ \text { A } & \text { mál } & \text { mal-ná } & \text { 'oil' } & \text { plural } \\ \text { B } & \text { kaalé-jı } & \text { kaaĺ́ } & \text { 'bird' } & \text { singulative } \\ \text { C } & \text { allá-n } & \text { alla-i(t) } & \text { 'ruler, leader' } & \text { replacement }\end{array}$

Intra- and intergenetic language contact led to intermediate stages of simplification of the system (Luwo, Thuri) without necessarily involving fundamental typological changes. The diversity of affixes found in Anywa is lost in Luwo, and Thuri lacks the singulative suffix found in most other Northern Lwoo languages, as well as in Burun and Nuer. Acoli, belonging to a different linguistic area, typologically changes from the proto-Lwoo system as it gives up the singulative category as such, as well as morphological plural formation for the greater part of its vocabulary.

\section{Structural borrowing in Belanda Bor}

We have seen that the prototypical tripartite system of Northern Lwoo noun morphology is basically kept in languages of the Western Bahr el-Ghazal. Although different stages of reduction can be observed, tripartite number marking has not been given up in the sample languages Luwo and Thuri, and a variety of suffixes 
are employed to mark the different number categories. As an example for Southern Lwoo, Acoli, which belongs to a different subgroup as well as to a different contact zone, exhibits fundamental typological changes as it loses the old tripartite number marking system and uses periphrastic plurals and some old, unproductive replacement patterns.

Being in close contact with the Ubangian language Bviri, Belanda Bor, a Northern Lwoo language, has undergone more radical changes than Acoli, Thuri or Luwo. Besides morphological changes, several phonological and syntactic convergences with Bviri are observed which, together with a hybrid lexicon, characterize Belanda Bor as a contact language that has lost many of its Nilotic features. While intragenetic diffusion led to an impoverished inventory of number marking morphemes in Luwo and intergenetic contact results in the reduction of number marking strategies in Thuri and Acoli, Belanda Bor has basically lost the rich number marking system of Western Nilotic. As we shall see, tripartite number marking patterns have, however, been retained and are expressed by completely different devices.

Belanda Bor has been influenced in particular by Bviri, a Sere language (Ubangi). Bviri also has a highly reduced number-marking system using morphologically marked plurals, which would be the basic pattern of Ubangi and other families within Niger-Congo. Borrowing of number-marking devices as well as lexical items point to long-lasting contact with Northern Lwoo; there are, however, traces of diffusion that suggest that more languages of different genetic stocks have participated in this contact.

4.1 Morphologically marked plurals. Number inflection in Bor at first glance only seems to involve formation of plurals, as the following examples help to illustrate. The singular forms are morphologically unmarked, while the plurals exhibit a prefix $k a$ - not found elsewhere in Northern Lwoo:

(9) Prefixation in Belanda Bor

$\begin{array}{lll}\text { 'skin', } & \text { deel } & \text { ká-deel } \\ \text { 'chest' } & \text { kóor } & \text { ká-kóor } \\ \text { 'woman' } & \text { dàkó } & \text { ká-mon } \\ \text { 'bone' } & \text { sògó } & \text { ká-sògó } \\ \text { 'voice' } & \text { yìit } & \text { ká-ỳiit } \\ \text { 'place' } & \text { fín } & \text { ká-fín } \\ \text { 'gazelle' } & \text { ródà } & \text { ká-ródà } \\ \text { 'fish' } & \text { réeo } & \text { ká-réeo }\end{array}$


The prefix appears with most plurals of nouns and never involves any tonal or phonological changes of the nominal stem (except the retention of an old suppletive plural for 'woman'). The suffixes normally employed in Lwoo numbermarking have been lost or are no longer grammatically productive. The prefixing technique resembles that of neighbouring Niger-Congo groups, and most likely is due to convergence with Ubangi.

Bviri marks its plurals in the same way. Again, plurals are constructed with a prefix $\mathrm{ka}$ - while singulars are morphologically unmarked. $\mathrm{Ka}$-, however, is not a grammatical element that can be reconstructed as a plural class marker in Ubangi. It is very likely that this morpheme is a feature of the $N / K$ area classically defined by Bryan (1968). The other Sere languages do not use $k a$ - as a plural marker, but employ ndá- as a uniform prefix for all nominal plurals, as can be seen in example (10a) below:

(10) a. Plural construction in Bviri (Santandrea 1961: 35 f.)

$\begin{array}{lll}\text { 'man' } & \text { dáko } & \text { ka-đáko } \\ \text { 'woman', } & \text { ni } & \text { ka-ni } \\ \text { 'calabash' } & \text { féngo } & \text { ka-féngo } \\ \text { 'knife' } & \text { mvàa } & \text { ka-mvàa } \\ \text { 'name' } & \text { lè } & \text { ka-lè } \\ \text { 'rat' } & \text { ju } & \text { ka-ju } \\ \text { 'scorpion' } & \text { sènè } & \text { ka-sènè }\end{array}$

b. Plural construction in the remaining Sere group

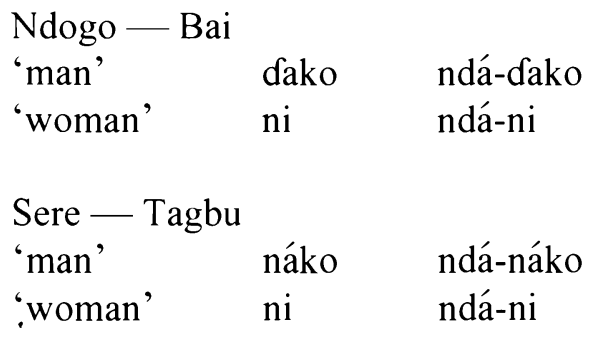

It seems, from looking at the greater part of the vocabulary, that Bor and Bviri use morphologically marked plurals that are characterized by $k a$-. This grammatical element is present in a number of languages which are part of the 
$N / K$ linguistic area, namely in Didinga-Murle, Tama, Daju, Temein, KadugliKrongo and Nilotic languages (cf. Bryan 1968).

4.2 Replacement pattern. Bor also has a large number of nouns that employ the replacement pattern for number marking. These are mostly nouns for persons, and - again - the formatives are entirely prefixes and thus differ typologically from the formatives of the other Lwoo languages. In example (11), the singulars of nouns denoting a person are constructed with a prefix $j i-$ or $j i$ - that appears in other Lwoo languages as well. According to Reh (1985: 56, cit. Dimmendaal 2000: 247) this prefix is derived from a common Western Nilotic root *jal- 'traveller'. The plurals substitute the $j i$ - prefix with $j o$-. The former compound noun thus has been reanalyzed as a prefixed replacive morpheme 'person' plus a noun stem functioning as a specifier.

(11) Replacement pattern in Bor

$\begin{array}{lll} & \text { sg. } & \text { pl. } \\ \text { 'liar' } & \text { ji-tòt } & \text { jò-tòt } \\ \text { 'owner' } & \text { ji-fàsí } & \text { jò-fàsí } \\ \text { 'friend' } & \text { jı-wòdò } & \text { jò-wòdò }\end{array}$

The replacement pattern is also employed as a number marking principle in the following example (12a). Here, the nominal derivative prefix di- 'child of' (Proto Nilo-Saharan * $d i$ 'young'; Ehret 2001: 299) alternates with the areally distributed plural prefix $k a ́$-. In other Lwoo languages, $d i$ - does not appear within the replacement pattern; compare Anywa in example (12b, cf. Reh 1996: 158).
(12)
$\begin{array}{llll}\text { a. } & \text { Bor }, & \text { sg. } & \text { pl. } \\ & \text { 'man' } & \text { dì-só } & \text { ká-sò }\end{array}$

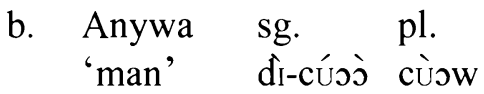

4.3 Singulatives. The third pattern prototypical of the Western Nilotic number marking system is the construction of singulatives. Again, Belanda Bor innovatively employs prefixes to construct this ancient Western Nilotic grammatical category. An item singled out of a mass of similar items is marked by a prefix niwhich goes back to a Western Nilotic root 'daughter of' (Reh 1996: 152). The 
collective is the morphologically unmarked form, from which the singulative is derived. The singulative in example (13) has the meaning of 'a drop of water'.

(13) Singulative in Bor

$\begin{array}{lll} & \text { singulative } & \text { collective } \\ \text { 'water' } & \text { jí-fì } & \text { fî }\end{array}$

Interestingly, both the underlying collective as well as the singulative noun have plurals. In both cases the additional general plural prefix ká- is employed:

(14) Innovative plural patterns in Bor

'quantities of water' ká-fil

'drops of water' ká-ní-fil

4.4 Innovations in Bviri. The fact that the three categories of the tripartite system in Bor have been retained, even though they use innovative strategies, shows that language contact does not necessarily include typological changes as we observed in Acoli. But which are the contact phenomena on the Ubangi (Bviri) side?

It seems that Bviri is incipiently developing into a singulative-marking language. As singulatives are not a historically original category within Niger-Congo the presence of the grammatical technique of constructing singulatives is interpreted as a result of structural borrowing from Nilotic. In the lexicon of Bviri, a number of nouns denoting items singled out from a mass of similar items are characterized by the prefix vo-. Examples are:

(15) Singulatives in Bviri (Santandrea 1961)

'bean'

'bee'

'groundnut'

'sand'

'grain, seed'

'sesame'

'star' singulative collective/root

vo-kùlù

vo-li

vo-kpolo

vo-kuyo

vo-na

vo-tú

vo-síŕ
${ }^{\circ}$ kùlù ${ }^{4}$

${ }^{\circ} \mathrm{li}$

${ }^{\circ}$ kpolo

kuyo

${ }^{\circ}$ ya

${ }^{\circ}$ tu

siri

${ }^{4}$ Forms that are marked with ${ }^{\circ}$ are the roots given by Santandrea. It is not clear to the author whether they take a prefix in the collective form. 
Santandrea (p. 34) remarks that the prefix vo- is derived from the noun 'seed of ...'; $v o-l i$ 'bee' literally means 'seed of honey'. Elsewhere in the Sere group, a root $n j i$ - is found for 'seed'. For 'edible grain', Ehret (2001) reconstructs a Proto-Nilo-Saharan root *wa:y or *'wa:y. Whether vo- and *(') wa:y are etymologically related is not yet clearly understood. It is, however, certain that Bviri borrowed the grammatical feature from Nilotic.

Other productive categories within the nominal system of Bviri are diminutives marked by the prefixes wi- (for persons) and ju- 'daughter' (for things; $\leftarrow$ Western Nilotic jo- ?), and agent nouns that are constructed with mve- 'owner of' (< Western Nilotic wun $\sim$ won $\sim$ wi ?). It is likely that Bviri here employs morphemes borrowed from neighbouring Nilotic languages, even though the respective grammatical categories have not necessarily been borrowed as well.

Bviri singulative constructions are the reinterpretation of the first component of a compound noun as a grammatical affix - a strategy that also occurs among noun class languages elsewhere (cf. Storch (forthcoming) for a similar case in Jukun). Unlike the nominal derivations with $w i-, j u$ - and $m v e-$, these forms are functionally different from the nominal categories found elsewhere in NigerCongo. Heavy reduction of a formerly rich nominal morphology can be compensated for in different ways, e.g. by convergence with Nilotic as well as rebuilding of genetically inherited grammatical categories. This leads to the assumption that contact-induced changes in the nominal system of Bviri occur in four strata:

1. Loss of the prototypical noun class system;

2. Convergence to areally distributed linguistic patterns $(N / K$ linguistic area);

3. Structural borrowing of the Western Nilotic singulative category;

4. (?) Borrowing of Nilotic derivational prefixes.

4.5 Other convergence phenomena. In Belanda Bor, we observe heavy structural borrowing in the nominal system insofar as the language has changed to the prefixing Ubangi type and has completely given up the suffixation of numbermarking morphemes. However the prototypical tripartite number marking system is retained and seems to have been restored several times by employing morphemes of different genetic origins. We distinguish: 
1. Plural (ká-): an areally distributed morpheme; possibly borrowed from Bviri;

2. Replacement pattern (ji-/jò-): a Western Nilotic root with derivative functions, reanalyzed as purely number marking morphemes;

3. Singulative (ni-): a Western Nilotic root, reanalyzed as a number marking morpheme.

Diffusion affected not just the nominal morphology of the languages; phonological features, patterns of verbal inflection, as well as syntactic patterns also diffused. Again, a multilateral direction of diffusion is observed; both Bor and Bviri developed morphological patterns (prefixation in Bor) and grammatical categories (singulative in Bviri) different from those of their respective close relatives. This is best illustrated by some of the commonest sound shifts in both languages:

(16) a. Affrication $(p \rightarrow p f \rightarrow f)$

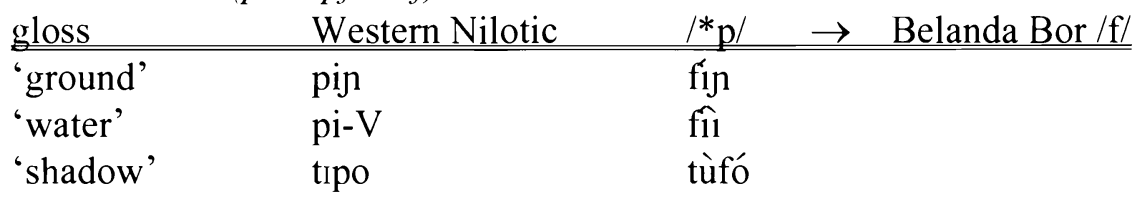

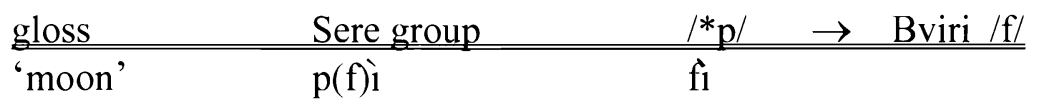

b. Spirantization $(c \rightarrow s)$

\begin{tabular}{llll} 
gloss & Western Nilotic & $\mid * \mathrm{c} /$ & $\rightarrow$ Belanda Bor $/ \mathrm{s} /$ \\
\hline 'milk' & $\mathrm{cak}$ & $\mathrm{sak}$ & \\
'bitter' & $\mathrm{k} \varepsilon \mathrm{c}$ & $\mathrm{k} \hat{\varepsilon} \mathrm{s}$ & \\
'bone' & $\mathrm{c} \mathrm{Go}$ & sògó
\end{tabular}

\begin{tabular}{llll} 
gloss & Sere group & $/ *_{\mathrm{c} /} \rightarrow$ Bviri /s/ \\
\hline & 'durra' & $\mathrm{cu}(\mathrm{u}) \mathrm{su}$
\end{tabular}

Whether the contact-induced changes described here are the results of a long-lasting coexistence of two ethnic groups, or are the consequence of recent and fast progressing pidginization processes cannot be answered satisfactorily at the present moment. Substantial data is lacking on most aspects of the deriva- 
tional morphology, the verbal system, syntactic patterns and discourse in both languages.

No interference has taken place in Bor in terms of the categories of number marking. Transfer of vocabulary, nominal morphology and phonological material from Bviri into Bor did not include or lead to the transfer of the nominal system, i.e. of Ubangi-Sere uniform plural marking. Whereas Acoli has only a few plurals for persons and hardly preserves any traces of the prototypical tripartite number marking system, Belanda Bor perfectly preserves this system even though it employs innovative strategies.

Bviri has not borrowed the Nilotic number suffixes, but transfer of derivational prefixes and the singulative number category seems to have taken place. Both languages converge in different domains of their number inflection system and noun morphology. The phonological findings fit well into this pattern: steady convergence makes Bor and Bviri phonologies more and more similar, while languages closely related to them do not converge or even exhibit a tendency towards borrowing any features from the Belanda amalgam.

\section{Historical perspectives}

The linguistic situation most certainly reflects the nature of contact in the area. Oral accounts of the Luwo and Shilluk indicate that there have been several migrations which led to the present geographical distribution of Lwoo-speaking peoples. Luwo tradition claims that after their ancestors had migrated from the south, three brothers - jikkán, dı̣mọ and àcóol - quarrelled and separated. As the group split into three, everybody went his own way, and while jikkán became the forefather of the Shilluk and àcóol became the ancestor of the Acoli, dı̀mò. became the ancestor of the Luwo and Thuri. The three groups did not share a close relationship anymore and began to live with people of different origin (author's field data). According to oral traditions interpreted by Tucker (1931: 50), the Luwo very successfully settled around Aweil where they assimilated other ethnic groups. Slave raids later made a large group of Luwo break away and migrate southwards, where they settled west of the Dinka country. The Dinka called them jùur (sg. júr) 'strangers' and refused to let them settle among them or to intermarry with them. The Jur-Luwo were taken as slaves and were generally regarded as inferior since they had no cattle. The Jur-Luwo groups eventually came under the rule of Dinka chiefs and partly assimilated to the Dinka.

Tucker further states: 
The Jur are excellent iron-workers, and still supply the Dinka with spears, where the two races meet. Although still regarded as the inferior race, they intermarry to a certain extent with the Dinka, the woman taking the nationality of her husband; there is also a fair amount of assimilation of Dinka customs (e.g., the tribal marking of boys' heads). They answer readily to the name of 'Jur' (the name no longer carrying with it its former insult), but among themselves they are still the Jo Luo. [p. 50]

The Thuri ("Shatt") split from the Luwo — possibly due to slave-raids and settled west of them, where they basically lived from hunting and farming, "the presence of 'fly' in their country preventing their having cattle" (Tucker 1931: 50). Other groups who split off from the Luwo are the Manangeer who largely became assimilated by the Dinka and now speak Dinka (author's field data), and the Demo or Dembo who apparently still speak Luwo.

The Bor also split off from the main body of the Luwo, according to their own traditions. Evans-Pritchard (1931) reconstructs a history of several waves of southward migrations. The last groups to reach the Bor area broke away from the Luwo only during the $19^{\text {th }}$ century. Earlier waves of migration into the area, however, seem to have taken place around the time of the Shilluk migrations of the $16^{\text {th }}$ century under chief jikán. Evans-Pritchard remarks on the Belanda amalgam:

Between the Pongo and the Iba there are settlements of people who have long been known as Belanda. This name comprises two distinct races and cultures, Shilluk [sic] and Basiri [sic], but through long residence in the same area there has been considerable cultural and probably racial admixture between them. Both have been repeatedly raided by the Azande [during the Azande invasions since the late $18^{\text {th }}$ century, A.S.] and have been partially absorbed by Zande political organization. [...] Our knowledge of the Bor is negligible, but one may hazard a conjecture that very little besides language is left of their Nilotic culture. [...] The other element of the Belanda amalgam are the Mbegumba. [...] They suffered severe shocks from the Zande invasion at the beginning of the $19^{\text {th }}$ century, and this invasion, aided by Arab slave-raiding activities, caused dispersion. The main body of Basiri [i.e. the group from which the Mbegumba have split off, A.S.] submitted to Zande rule and remained a cohesive group. [...] Others migrated north-eastwards and settled in the hills between Tembura post and the Bo river. Here they were again disturbed by Azande and Arabs and a secondary dispersion took place, resulting in the formation of pockets widely separated from each other. [p. 42]

This account of oral history helps to illustrate the nature of "lingualism" in the research area. The Luwo - in spite of the assimilation of other groups during 
their early migrations - have remained a stable and comparatively large group and only a few generations ago came into close contact with the Dinka. This led to a high degree of bilingualism in Luwo and Dinka which also resulted in the reduction of the rich inflectional morphology which Northern Lwoo languages otherwise have. However the language retained its suffixing number-marking system. The Thuri have become a very small group of migrant hunters and farmers who have been exposed to numerous groups speaking genetically unrelated, typologically different languages. As a result of contact with prestige languages such as Ndogo, and because of the small number of Thuri speakers who must have been bi- or trilingual, Thuri changed considerably, resulting in a reduced but still tripartite number-marking system.

The Belanda Bor in turn were cut off from the main Luwo body so completely in the middle of the $19^{\text {th }}$ century, that their social system as well as their cultural heritage seems to have rapidly vanished when the group was dominated by Ubangi-speaking peoples. It is intriguing that the language seems to have been the only Nilotic feature of the people's cultural and social heritage to have been preserved. Its special functions in the religious life of the people might have prevented it from being given up in favour of Bviri or Sere. The possibly symbiotic relationship with the Bviri lasted at least two centuries, and the enormous pressure from outside (Zande invasions, slave raids) could have led to the amalgamation of the groups. What role language played in the construction of an ethnic identity remains unclear.

Unlike Luwo-speaking groups, where bilingualism could have been sporadic for a long time and involved genetically related languages, the Belanda have developed into a strictly bilingual society where it was obligatory to speak at least one additional, genetically unrelated language. An important factor explaining the heavy structural and lexical borrowing in Belanda Bor seems to have been the low prestige this language has in the area ("The Jur despised by the Dinka and despising the Bor" (Tucker 1931: 59)). Being affiliated to a culturally prestigious, powerful group such as the Zande and Sere could have been a crucial strategy for survival.

\section{Aspects of change in Western Nilotic number marking}

The diversity in number marking morphology and morphophonology within Western Nilotic has not yet allowed for reconstruction of the proto-system. Poor documentation of many Western Nilotic languages as well as inappropriate descriptive techniques in many of the earlier, pioneering studies of this family have 
led to the common impression that this sub-family has undergone changes radical enough to completely erode the formatives and patterns of the proto-system. Once language contact situations such as between Bviri and Belanda Bor are better understood, the elements that disrupt regular historical correspondences can be defined and controlled for purposes of reconstruction.

Patterns of tripartite number inflection are found almost everywhere in Western Nilotic - fully developed in Anywa and rudimentary in Southern Lwoo. It is not easy to decide whether simple memorizing of the "irregular" plurals in Western Nilotic languages would have conserved the system. Dimmendaal (2000) shows that the tripartite number marking system is present in almost all branches of Nilo-Saharan and should be consideration to be genetically inherited by the languages within this phylum. Our own findings from Belanda Bor and the Belanda Bviri data suggest that the prototypical system could have spread dynamically in areas of intensive language contact.

If the tripartite system is assumed to have originated in a Nilo-Saharan or even Western Nilotic proto-language, reconstruction should be possible. Gilley (2000) is able to show that Shilluk singulars and plurals are constructed according to a system of phonological and semantical rules. Some of the singular-plural patterns seem to go with particular semantic concepts, an observation also made by Andersen (1998) for Mabaan, where a certain pattern of plurals occurs with nouns denoting longish objects.

Dimmendaal (2000) also suggests that phonological patterns of the noun stem are responsible for the choice of a particular number marking morpheme. This seems particularly to hold true for Surmic and Eastern Nilotic (pp. 220 ff.; $233 \mathrm{ff}$.). This latter approach is likely to produce interesting results in the Western Nilotic Burun languages which have a very rich inflectional morphology, but as far as Dinka, Nuer and probably a number of Lwoo languages are concerned, the extremely complex phonological systems of these languages do not easily allow for a (re-)construction of the phonological rules of number marking strategies.

Besides exploring the semantic and phonological dimension of Western Nilotic number marking, the history of language contact and the understanding of linguistic areas in the Western Nilotic zone are of crucial importance. Language contact as one possible reason for modifications of the proto-system has not yet been studied intensively. Our understanding of the nature of modifications in the proto-system of the respective languages could be deepened if language contact in the highly heterogeneous area of Western Nilotic were better described and strata of intergenetically borrowed features were identifiable. The semantic patterns governing plural classes as well as the set of morphophonological rules could 
then be compared to the strategies of number marking in the contact languages in order to understand the dynamics and development of the system.

For the Belanda case, further research on bilingualism is urgently needed. During the last thirty years much of Bahr el-Ghazal has been devastated by war, and according to Belanda Bor speakers interviewed in Khartoum, most of the Belanda have been dispersed or have fled from the area. In Haj Yusif quarter of Khartoum, where displaced Southern Sudanese settle, Belanda Bor and Belanda Bviri live in different areas and do not speak each other's language any more. Their children still grow up bilingually, now speaking Bor or Bviri respectively and a pidginized Arabic. It is likely that Belanda Bor and Bviri bilingualism in Bahr el-Ghazal will come and the villages will become uninhabitable due to the ongoing civil war. It is only after more research on these fast disappearing languages and linguistic areas has been conducted, that we will come to a better understanding of the factors that determine the modification of noun morphology in Western Nilotic.

\section{REFERENCES}

Andersen, Torben. 1987. "The phonemic system of Agar Dinka". Journal of African Languages and Linguistics 9: 1-27.

Andersen, Torben. 1988a. "Consonant alternation in the verbal system of Päri" Afrika und Übersee 71: 63-113.

Andersen, Torben. 1988b. "Downstep in Päri: The tone system of Western Nilotic language". Studies in African Linguistics 19: 261-315.

Andersen, Torben. 1988c. "Ergativity in Päri, a Nilotic OVS language". Lingua 75: 289-324.

Andersen, Torben. 1989. "The Päri vowel system with an internal reconsruction of its historical development". Journal of African Languages and Linguistics 11: 1-20. 
Andersen, Torben. 1992. "Aspects of Mabaan tonology". Journal of African Languages and Linguistics 13: 183-204.

Andersen, Torben. 1995. "Morphological stratification in Dinka: On the alternations of voice quality, vowel length and tone in the morphology of transitive verbal roots in a monosyllabic language". Studies in African Linguistics 23: 163.

Andersen, Torben. 1998. "Layers of number inflection in Mabaan (Western Nilotic)". Handout. 7th Nilo-Saharan Conference. Vienna.

Andersen, Torben. 1999a. "Layers of number inflection in Mabaan". Ms. NiloSaharan Conference. Vienna.

Andersen, Torben. 1999b. "Consonant alternation and verbal morphology in Mayak (Northern Burun)". Afrika und Übersee 82: 65-97.

Andersen, Torben. 1999c. "Vowel harmony and vowel alternation in Mayak (Western Nilotic)". Studies in African Linguistics 28: 1-29.

Andersen, Torben. 1999d. "Vowel quality alternation in Mabaan and its Western Nilotic history". Journal of African Languages and Linguistics 20: 97-120.

Andersen, Torben. 2001. "Number Inflection in Mayak (Northern Burun)". "Mehr als nur Worte..." Afrikanistische Beiträge zum 65. Geburtstag von Franz Rottland, ed. by Rainer Vossen, Angelika Mietzner and Antje Meissner. Cologne: Koeppe. Pp. 29-43.

Behagel, A. 1988. "Lexique". Lexique comparatif des langues oubanguiennes, ed. by Yves Monino. Paris: Geuthner Pp. 98-146.

Boyd, Raymond. 1989. "Adamawa-Ubangi”. The Niger-Congo Languages, ed. by John Bendor-Samuel. Lanham. New York: University Press of America. Pp. 178-215.

Boyd, Raymond and Helma Pasch. 1988. "Le groupe sere-ngbaka-mba". Lexique comparatif des langues oubanguiennes, ed. by Yves Monino. Paris: Geuthner. Pp. 50-58. 
Bryan, Margaret. 1968. "The ${ }^{*} \mathrm{~N} /{ }^{*} \mathrm{~K}$ languages of Africa". Journal of African Languages 7.3: 169-217.

Buth, Randall. 1981a. "Ergative word order - Luwo is OVS". Occasional Papers in the Study of Sudanese Languages 1: 74-90.

Buth, Randall. 1981b. "The twenty vowels of Dhe Luwo (Jur Luo, Sudan)". NiloSaharan, ed. by Thilo Schadeberg and Lionell Bender. Dordrecht: Foris. Pp. 119-132.

Dimmendaal, Gerrit. 1988. "The lexical reconstruction of Proto-Nilotic: A first Reconnaissance". Afrikanistische Arbeitspapiere 16: 5-67.

Dimmendaal, Gerrit. 2000. "Number marking and noun categorization in NiloSaharan languages". Anthropological Linguistics 42.2: 214-261.

Dimmendaal, Gerrit. 2001a. "Areal diffusion versus genetic inheritance: An African perspective". Areal Diffusion and Genetic Inheritance, ed. by A. Y. Aikhenvald and R.M.W. Dixon. Oxford: OUP. Pp. 358-392.

Dimmendaal, Gerrit. 2001b. "Language shift and morphological convergence in the Nilotic area". Cologne: Koeppe. SUGIA 16/17: 83-124.

Ehret, Christopher. 2001. A Historical-Comparative Reconstruction of NiloSaharan. Cologne: Koeppe.

Evans-Pritchard, Edward. 1931. "The Mberidi (Shilluk group) and Mbegumba (Basiri group) of the Bahr-el-Ghazal". Sudan Notes and Records 14: 15-48.

Gilley, Leoma. 1991. "Underlying representations in Shilluk: Is one enough?". Proceedings of the Fourth Nilo-Saharan Conference, Bayreuth, Aug. 30. Sep. 2., 1989, ed. by Lionel Bender. Hamburg: Buske. Pp. 165-174.

Gilley, Leoma. 1992. An Autosegmental Approach to Shilluk Phonology. Dallas: SIL. 
Gilley, Leoma. 2000a. "Singulars and plurals in Shilluk". Occasional Papers in the Study of Sudanese Languages 8: 1-21.

Gilley, Leoma. 2000b. "Some aspects of stress and tone in Shilluk". Unpubl. ms., SIL Khartoum.

Jungraithmayr, Herrmann and Rudolf Leger. 1993. "The Benue-Gongola-Chad Basin - Zone of ethnic and linguistic compression". Berichte des Sonderforschungsbereichs 268, Vol. 2, ed. by Guenter Nagel. Frankfurt / Main: University of Frankfurt. Pp. 161-172.

Knappert, Jan and Joseph Ukoko. 1964. Essai de dictionnaire dho alur. Ghent: Rijksuniversiteit te Gent.

Kohnen, B. Frater. 1933. Grammar of Shilluk. Verona: Missioni Africane.

Leslau, Wolf. 1945. "The influence of Cushitic on the Semitic languages of Ethiopia". A problem of substratum. Word 1: 59-82.

Nebel, Arturo. 1948. Dinka Grammar (Rek-Malual Dialect) with Texts and Vocabulary. Verona: Missioni Africane.

Noonan, Michael. 1992. A Grammar of Lango. Berlin: De Gruyter.

Reh, Mechthild. 1996. Anywa Language: Description and Internal Reconstruction. Cologne: Koeppe.

Reh, Mechthild. 1999. Anywa-English and English-Anywa Dictionary. Cologne: Koeppe.

Rottland, Franz. 1981. "Die nilotischen Sprachen". Die Sprachen Afrikas, ed. by Bernd Heine, Thilo Schadeberg and Ekkehard Wolff. Hamburg: Buske. Pp. 267-277.

Santandrea, Stefano. 1931. "The Belanda, Ndogo, Bai and Sere in the Bahr-elGhazal". Sudan Notes and Records 14: 161-179.

Santandrea, Stefano. 1946. Grammatichetta Giur. Verona: Missioni Africane. 
Santandrea, Stefano. 1961. Comparative Outline-Grammar of Ndogo - Sere Tagbu - Bai - Bviri. Bologna: Nigrizia.

Simeoni, Antonio. 1978. Päri: A Luo Language of Southern Sudan. Bologna: Nigrizia.

Storch, Anne. 2003. "Layers of Language Contact in Jukun". Dynamics of Language Systems in the West African Sahel, ed. by Petr Zima, Jan Jenik and Vladimir Tax. Prague: SOFIS. Pp. 176-196.

Thomason, Sally. 2001. Language Contact. An Introduction. Edinburgh: Edinburgh University Press.

Tucker, Archibald N. 1931. "The tribal confusion around Wau". Sudan Notes and Records 14: 49-60.

Tucker, Archibald N. 1994. A Grammar of Kenya Luo (Dholuo). 2 Vols. Cologne: Koeppe.

Westermann, Dietrich. 1927. Die westlichen Sudansprachen und ihre Beziehungen zum Bantu. Berlin: De Gruyter.

Westermann, Dietrich. (n.d.). A Short Grammar of the Shilluk Language. Philadelphia - Berlin: Vohsen.

Williamson, Kay. 1985. "How to become a Kwa language". Linguistics and Philosophy. Essays in Honour of Rulon S. Wells, ed. by Adam Makkai and Alan Melby. Amsterdam \& Philadelphia: John Benjamins. Pp. 427-443.

Institut für Afrikanische Sprachwissenschaften Johann Wolfgang Goethe-University

Dantestr. 4-6

60054 Frankfurt

Germany

storch $(\omega$ ) em.uni-frankfurt.de
[Received June 21, 2003 accepted December 20, 2003] 
